\title{
The new "global": the role of cargo maritime transport of goods with focus on the transportation corridor between Southeast Asia and Northwestern Europe
}

\author{
Marek Minárik ${ }^{1, *}$, and Denisa Čiderová ${ }^{1}$ \\ ${ }^{1}$ University of Economics in Bratislava, Faculty of Commerce, Department of International Trade, \\ Dolnozemská cesta 1, 85235 Bratislava 5, Slovak Republic
}

\begin{abstract}
.
Research background: Our research is framed by the new institutional theory reflected in: the property rights theory [1] and transfer of ownership of goods and the transaction costs theory that might be associated with economic exchange theory. Overall, we need to consider occurrence of deglobalization and the COVID-19 crisis, which recently not just decelerated growth of the world economy, but even put it to a halt; one might conclude that (de)globalization [2] and the COVID-19 crisis are behind the new "global" [3].

Purpose of the article: We investigate the impact of connectivity between selected countries by cargo maritime transport on costs to import of 1 TEU container transporting a specific commodity in a specific transportation corridor.

Methods: Our research is based on a regression analysis creating a model of UNCTAD statistics; the Liner shipping connectivity index (LSCI); and the WEF Global Competitiveness Index (GCI). We consider the Belt and Road Initiative (BRI) that converges with the global maritime transportation corridor between (Southeast) Asia/China - Northwestern Europe/EU (the North Sea Region) in this respect, bearing in mind the 2017 round of the International Comparison Program recently released by the World Bank.

Findings \& Value added: Our research reveals correlation of the costs to import of 1 TEU container vis-à-vis the quality and intensity of liner shipping connections and the quality of the business environment determining the transaction costs in import price. Value added of the paper is our focus on sustainable development reinvigorated by prestigious international organisations and European Union institutions.
\end{abstract}

Keywords: (de)globalization; Belt and Road Initiative (BRI); cargo maritime transport and maritime ports; TEU container; theory development (theory of ownership/property rights; transaction costs theory; contract theory)

\footnotetext{
*Corresponding author: marek.minarik@euba.sk
} 
JEL Classification: $F 14 ; F 60 ; M 21 ; N 75 ; R 40$

\section{Introduction}

Maritime transport has been a major driving force behind international exchange of goods throughout the history of the mankind, but particularly since the Ocean Age [3]. Nowadays, the biggest maritime ports of regional just like global importance are located in Southeast Asia and Northwestern Europe, which converge with the Chinese One Belt, One Road (OBOR) initiative (alias the Silk Road Economic Belt and a Maritime Silk Road, later reformulated as the Belt and Road Initiative - BRI).

Considering the purpose of our paper (to investigate the impact of connectivity between selected countries by cargo maritime transport on costs to import of 1 TEU container transporting a specific commodity in a specific transportation corridor) and the fact that over 130 countries have signed a Memorandum of Understanding to join the BRI, in our article oriented on the maritime transportation corridor between Southeast Asia and Northwestern Europe we focus within the BRI on East Asia \& Pacific and Europe \& Central Asia only.

On the one hand, Southeast Asia is in our focus within East Asia \& Pacific (BRI) represented by: China (ports such as Shanghai, Ningbo-Zhoushan, Qingdao, Tianjin, Xiamen, Dalian, the port of Hong Kong), Taiwan (port of Kaohsiung), Singapore, South Korea (port of Busan), Malaysia (port of Tanjung Pelepas), Thailand (port of Laem Chabang), Vietnam (port of Saigon Ho Chi Minh City) and Philippines (port of Manila).

On the other hand, Northwestern Europe is in our focus within Europe \& Central Asia (BRI) represented by: Belgium (ports such as Rotterdam and Antwerp), Germany (ports such as Hamburg and Bremerhaven), the United Kingdom (ports such as Felixstowe, Southampton and London) and France (port of Le Havre in the North Sea region).

Based on data from the recently released World Bank International Comparison Program (2017 edition) [4], the cumulative share of these countries from Southeast Asia and Northwestern Europe in world total GDP (PPPs) and population terms is $31.2 \%$ and $27.3 \%$, respectively. Their individual GDP per capita (PPPs) is in the interval between $43.3 \%$ and $566.3 \%$ (world $=100$ ). Analogically, heterogeneity of both groups of countries (covered in detail in Table A-1 in Annex) is further demonstrated by their ranking on the scale of: the 2017-2018 Global Competitiveness Index [5] launched by the World Economic Forum four decades ago and monitoring competitiveness, as well as the 2017 SDG Index [6] mapping sustainability, which was defined by the United Nations' World Commission on Environment and Development in 1987.

According to the World Shipping Council [7], the trade corridor between Asia and Northern Europe records 15063000 TEU containers in total. Focusing on the direction of the container flow, we claim that the westbound direction with 9924000 TEU containers counts with much higher transport performance than the eastbound direction with the 5139000 TEU containers. These data confirm the fact that the world production area is located in the region of Southeast Asia and one of the consumption areas is located in Europe.

One of new ideas in logistics is the batch size one production based on 3-D printing, toplevel robotics and automation. 3-D as an example of the new "global" will increasingly have an impact on transport [8] and new logistical methods will result in modified transportation of goods [9].

This article deals with the issue of the costs to import 1 TEU container. We identify these costs with the freight rates or quotes. Eurosender [10] is a modern digital platform, which combines advanced possibilities of automation, enables companies to create their own digital logistics departments and to raise their performance.

There are several components to calculate the rates for transporting goods by sea such as the size and weight of transported goods (dimensions), distance (lower rates for long-haul 
shipments), inland transportation for connecting the port to delivery address (pick-up and delivery), the nature of goods (type of item), extra coverage for additional protection of cargo (insurance), customs clearance (fees for international maritime cargo shipments) and Incoterms clauses. Analysis in Table A-2 in Annex is based on strengths and weaknesses of the maritime transport modality. E.g. modern maritime transport is less problematic than the air transport in terms of environmental impact, which relates mainly to the carbon footprint and $\mathrm{CO}_{2}$ emissions [11].

\section{Research background}

\section{1 (De)globalization and the COVID-19 crisis}

Globalization represents one of key concepts in the 21 st century and it will undoubtedly continue to be analysed. Due to intensifying interdependence of countries and communities, globalization as a multi-dimensional process is characterised by: "the acceptance of a set of economic rules for the entire world designed to maximise profits and productivity by universalising markets and production, and to obtain the support of the state with a view to making the national economy more productive and competitive; technological innovation and organisational change centred on flexibilisation and adaptability; the expansion of a specific form of social organisation based on information as the main source of productivity and power; the reduction of the welfare state, privatisation of social services, flexibilisation of labour relations and weaker trade unions; de facto transfer to trans-national organisations of the control of national economic policy instruments, such as monetary policy, interest rates and fiscal policy; the dissemination of common cultural values, but also the re-emergence of nationalism, cultural conflict and social movements." [12]. Thus, besides economic [13] and political [14] aspects globalization relates to a spectrum of features. Currently, in the context of globalization theory there are several approaches: World-System Theories; Theories of Global Capitalism; The Network Society; Theories of Space, Place and Globalization; Theories of Transnationality and Transnationalism; Modernity, Postmodernity and Globalization; and Theories of Global Culture. Moreover, we can differentiate: Theory of Liberalism; Theory of Political Realism; Theory of Marxism; Theory of Constructivism; Theory of Postmodernism; Theory of Feminism; Theory of Transformationalism and Theory of Eclecticism (as globalization theory categories listed on the Political Science website and cited in [12]).

Among key theorists of globalization let us focus on the view of the 2001 Nobel Prize laureate J. Stiglitz explaining the new status quo of today's fast-changing world: "In the last quarter century we've had the Argentine crisis, the Russian crisis, the East Asia crisis, the global financial crisis, and the euro crisis. [...] While the standard model a quarter century ago was based on rational households and firms interacting in competitive markets in ways that achieved efficiency and stability, each of the underlying assumptions has come to be questioned: firms and households often act in a far-from-rational manner; markets are often not competitive; and the outcomes often seem far from efficient or stable.". Thus, globalization is not to be understood as "an end in itself, but, possibly, if it's made to work right, a means to an end [i.e. higher living standards on a more extensive (alias inclusive) rather than a more intensive (alias exclusive) basis, as a result of more equitably shared benefits of globalization [12]]. Too often, the advocates of globalization confuse ends and means. They continue to glorify globalization, even when it appears to harm a majority of the citizenry, or at least a large portion of it", Stiglitz [2] claims and calls for the so-called "reformed globalization". 
We are aware of the trajectory moving on from "globalization so far" (e.g. demand for more, and more diverse goods and services; global supply chains [15]) on the wave of "trends [12] changing globalization" (e.g. demand for more fair trade, sustainable and local products; global value chains) as framed by the European Commission, the McKinsey Global Institute and the OECD in Table A-3 in Annex.

The novel coronavirus COVID-19 "provokes the reckoning of the balance sheet of globalization, and the policy challenge of promoting the positive sides while limiting the negative consequences", J. Sachs [3] argues. Authorities pursued various degrees of the socalled lockdown since the early stages of the COVID-19 pandemic. [16] "Quarantines are back, the word itself referring to the forty days (quaranta giorni in Italian) that Venetians held ships away from the port when the ships were suspected of carrying plague. [...] Throughout history, it has been important to understand the threats arising from globalization (disease, conquest, war, financial crises, and others) and to face them head on, not by ending the benefits of globalization, but by using the means of international cooperation to control the negative consequences of global-scale interconnectedness", J. Sachs [3] continues.

\subsection{New institutional theory}

D. North linked in his publication titled Institutions, Institutional Change and Economic Performance [17] the development and economic growth to transaction costs. Transaction costs in export or import prices belong to the most important determinants of market exchange [18].

For the purpose of our research we identify transaction costs with the costs of exchange between the seller and the buyer that arise from the legal institute of complete international contract of sales, its interpretation of the delivery of goods and the transfer of risks and ownership without reservation within the trade channel. In this context, transaction costs represent the price wedge in the space between the manufacturing point EXW (Ex works) in the exporter's country and the final destination DDP (Delivery duty paid - free circulation) in the importer's country. We suppose that only in this way we are able to incorporate not just transport and logistics in export or import prices [19], but rather all economic, social and ecological aspects of any transaction.

The synthesis of several views (Coase, Williamson, Cheung, Wallis, North, Polski and Soto) for defining and measuring transaction costs has been dealt with by several authors According to these approaches and our view presented above, measuring of transaction costs can also be based on the difference between the price paid by the buyer and the price received by the seller (value of transfer of ownership of negotiable goods, bounded rationality, opportunism and asset specificity [18]).

The main impact of globalization on the structure of transaction costs in export or import prices is identified in the importance of time, space and knowledge as main forces behind the wealth of countries. This is also a basis for other authors that address the issue of transaction costs or the costs of exchange from the point of view of the value of time [20].

In addition to the transportation corridor, the transported commodity is also important in the issue of transaction costs. Therefore, our investigation is based on the commodity of electronic components and supplies of the value of 20000 USD per 1 handling unit, which is the container of twenty foot equivalent unit (TEU) in FCL regime, i.e. full container load. 


\section{Methods}

Data of the Global Competitiveness Index 2017-2018 are based on the WEF Global Competitiveness Report 2017-2018 [5], data of the Liner shipping connectivity index 2017 [21] are based on UNCTAD statistics [22].

Competitiveness is defined by the World Economic Forum (WEF) as "the set of institutions, policies, and factors that determine the level of productivity of a country" [5]. The Global Competitiveness Index (GCI) stands for a composite index comprising in the 2017-2018 edition of the WEF Global Competitiveness Report 114 indicators grouped into 12 pillars of competitiveness (institutions; infrastructure; macroeconomic environment; health and primary education; higher education and training; goods market efficiency; labour market efficiency; financial market development; technological readiness; market size; business sophistication; innovation). Hard data from international organisations are complemented with soft data originating in the WEF Executive Opinion Survey.

The Liner shipping connectivity index (LSCI) records how well countries are connected to the global shipping network. It is based on 5 components related to maritime transport such as number of ships, the container-carrying capacity of the ships, maximum vessel size, number of services and number of container ships companies that operate in analysed country's ports. The UNCTAD methodology of calculating this index [23] is based on data from the reference year 2004 and from the actual year. The value for each component in the actual year is divided by the maximum value of the same component in the reference year 2004 and the result is multiplied by 100. The resulting value for the whole index is calculated as an average of the values in the actual year divided by the maximum average for the reference year 2004. The final result is multiplied by 100 [21].

The database of the LSCI for the countries, where the analysed ports are located, and the GCI for the countries, where the analysed ports are located, was completed with the costs to import 1 FCL TEU container of the analysed commodity in analysed transportation corridor (westbound direction). The data of the costs to import 1 FCL TEU container come from the freight calculator of the World Freight Rates website [24]. The calculator works in four steps such as the selection of the method of shipping (containerized, break bulk, project cargo/heavy lift, truck and air), the selection of locations (origin port, destination port, transported commodity, the value of the transported commodity), the LCL or FCL regime and container type (TEU, FEU, $45 \mathrm{ft}$ and refrigerated container) and finally the accessorial charges for hazardous goods or insurance. For our research, we chose containerized shipping method, ports of origin and destination coincides with the European and Asian ports indicated above, the transported commodity and its value is mentioned above, too. We did not choose any accessorial charges. This allowed us to get rates for the import of 1 TEU container for each Asian-European pair of the analysed ports and to create a final database. The database was processed in the form of a regression analysis and model of dependence of the costs to import 1 TEU container to Rotterdam on the values of both, the LSCI just like the GCI using the Gretl statistical program.

The tool for fulfilling the main purpose of this article was the hypothesis, which we have formulated in the following forms:

H1: The costs to import 1 TEU container from the Southeast Asian ports to Rotterdam are sensitive to changes in the quality and intensity of the connections to global liner shipping network.

To expand the main purpose of the article and to create a more comprehensive view of the issue, we formulated another hypothesis, too, as follows:

H2: The costs to import 1 TEU container in westbound direction of the analysed transportation corridor depend, among other aspects, on the quality of the business environment. 
The indicator of the costs to import 1 TEU container from the Southeast Asian ports to Rotterdam was identified in the regression model with the dependent variable. The indicators of the LSCI and the GCI were identified in the regression model with the independent variables. The data for the dependent variable for the model are from the year 2020 and to ensure at least one-year time lag in the effects of the independent variable on the dependent one, the data for the independent variables for the model are from the year 2017 or $2017 / 2018$.

The main purpose of this article was based on stating the possible relationship between the costs to import $1 \mathrm{TEU}$ container and the value of the Liner shipping connectivity index. The very existence of the relationship between these variables confirms that the costs to import 1 TEU container are sensitive to changes in the quality and intensity of the connections to global liner shipping network.

The OLS estimator in the Gretl statistics program was used to create the regression model, but due to the presence of the heteroskedasticity, we used more suitable Heteroskedasticity corrected estimator. Using this estimator, it was possible to meet the homoskedasticity condition. The final linear regression model has the following general equation:

$$
y_{i}=\beta_{0}+\beta_{1} x_{i 1}+\beta_{2} x_{i 2}+u_{i}
$$

\section{Results and discussion}

Based on our database we assume we could create a regression model of dependence of the costs to import 1 TEU container to the ports in the North Sea like Rotterdam, Hamburg, Antwerp, Felixstowe and others from the ports in the Southeast Asia like Shanghai, NingboZhoushan, Hong Kong, Busan, Singapore, Saigon Ho Chi Minh City and others on the LSCI and GCI. This fact indicates that there is a type of relation between the costs to import 1 TEU container and the indices, which characterise the quality of the liner shipping connections of the analysed countries and the quality of the business environment of the same analysed countries. We consider both of them as basis for the transaction costs in export or import price. The following Table 1 introduces the model mentioned above. 
Table 1. Model Heteroskedasticity-corrected, using observations 2-15 $(n=14)$, Dependent variable: 1_Costs_Import_to_Rotterdam_2020.

\begin{tabular}{|l|c|c|c|c|l|}
\hline & Coefficient & \multicolumn{1}{|c|}{ Std. Error } & t-ratio & $p$-value & \\
\hline Const & \multicolumn{1}{|c|}{8.48978} & \multicolumn{1}{|c|}{0.725158} & 11.71 & $<0.0001$ & $* * *$ \\
\hline 1_LSCI_2017 & 0.196439 & 0.0599729 & 3.275 & 0.0074 & $* * *$ \\
\hline 1_GCI_20172018 & -1.29583 & 0.471591 & -2.748 & 0.0190 & $* *$ \\
\hline Sum squared resid & 20.29277 & S.E. of regression & 1.358233 \\
\hline R-squared & 0.561051 & Adjusted R-squared & 0.481243 \\
\hline F(2,11) & 7.029941 & P-value(F) & 0.010796 \\
\hline Log-likelihood & -22.46359 & Akaike criterion & 50.92718 \\
\hline Schwarz criterion & 52.84435 & Hannan-Quinn & 50.74971 \\
\hline Mean dependent var & 7.283456 & S.D. dependent var & 0.117227 \\
\hline Sum squared resid & 0.102686 & S.E. of regression & 0.096618 \\
\hline
\end{tabular}

Source: Own processing based on data from $[5,21,24]$ using Gretl statistical program.

The linear regression model was also tested for normality of residual - Null hypothesis: error is normally distributed, Test statistic: Chi-square $(2)=0.178838$ with p-value $=$ 0.914462 .

The equational final form of our regression model is:

In Costs_to_Import_to_Rotterdam_2020

$$
\begin{aligned}
& =8.49+0.196 * \ln \text { LSCI_2017 }-1.30 \\
& * \ln \mathrm{GCI} 20172018(0.725)(0.0600)(0.472), \mathrm{n} \\
& =14, \mathrm{R}-\text { squared } \\
& =0.561 \text { (standard errors in parentheses) }
\end{aligned}
$$

This equation says that the linear regression model (Table 2) is based on the following interpretation: if the value of the LSCI (the variable of 1_LSCI_2017) is increased by $10 \%$ and the value of the GCI (the variable of 1_GCI_20172018) is unchanged, the costs to import 1 TEU container to the port of Rotterdam from the Southeast Asian ports from our database (China's ports - Shanghai, Ningbo-Zhoushan, Qingdao, Tianjin, Xiamen, Dalian; Taiwan's port Kaohsiung, Singapore, Hong Kong, South Korea's port Busan, Malaysia's port Tanjung Pelepas, Thailand's port Laem Chabang, Vietnam's port Saigon Ho Chi Minh City and Phillipines' port Manila) would increase by $1.96 \%$.

If the value of the GCI (the variable of 1_GCI_20172018) is increased by $10 \%$ and the value of the LSCI (the variable of 1_LSCI_2017) is unchanged, the costs to import 1 TEU container to the port of Rotterdam from the same Southeast Asian ports would decrease by approximately $13 \%$. 
Table 2. Confidence interval $\mathrm{t}(11,0.025)=2.201$.

\begin{tabular}{|c|c|c|}
\hline Variable & Coefficient & 95 confidence interval \\
\hline Const & 8.48978 & $(6.89372,10.0858)$ \\
\hline 1_LSCI_2017 & 0.196439 & $(0.0644391,0.328438)$ \\
\hline 1_GCI_20172018 & -1.29583 & $(-2.33380,-0.257871)$ \\
\hline
\end{tabular}

Source: Own processing based on data from $[5,21,24]$ using Gretl statistical program.

Data from Table 2 show that if the value of the variable of LSCI increases by $10 \%$, the costs to import 1 TEU container to Rotterdam from the Southeast Asian ports from our database would increase by more than $0.64 \%$ and less than $3.28 \%$.

If the value of the variable of GCI increases by $10 \%$, the costs to import 1 TEU container to Rotterdam from the Southeast Asian ports from our database would decrease by more than $2.58 \%$ and less than $23.34 \%$.

The independent variables from our regression model were tested too, the test for the variable 1_LSCI 2017 was processed as following: $\mathrm{H}_{0}: \quad \beta 1=0, \mathrm{H}_{1}$ : $\beta 1 \neq 0,|(0 . \overline{1} 96439-0) / 0.0599729|>2.201 ; 3.2755>2.201$. We reject the hypothesis $\mathrm{H}_{0}$ - the coefficient for the independent variable 1_LSCI_2017 has been confirmed as statistically significant. The value of the LSCI (the quality and the intensity of the liner shipping connections among countries) affects the costs to import 1 TEU container.

The test for the variable 1_GCI_20172018 was processed as following: $\mathrm{H}_{0}: \beta 1=0, \mathrm{H}_{1}: \beta 1$ $\neq 0,|(-1.29583-0) / 0.471591|>2.201 ; 2.7478>2.201$. We reject the hypothesis $\mathrm{H}_{0}$ - the coefficient for the independent variable 1_GCI_20172018 has been confirmed as statistically significant. The value of the GCI (the quality of the business environment) affects the costs to import 1 TEU container.

The regression model as a whole (Table A-4 in Annex) is statistically significant, too, due to its verification for the statistical significance at the level of significance $\alpha=0.1$. Hypothesis $\mathrm{H}_{0}$ depicts the fact that the linear regression model is not statistically significant, the hypothesis $\mathrm{H}_{1}$ depicts the fact that the linear regression model is statistically significant. The critical value of $F_{0,1}(2.11)=3.9823$; the $F$ value from our regression model is 7.029941 . Since $7.029941>3.9823$, the null hypothesis $\mathrm{H}_{0}$ is rejected.

Also the $\mathrm{p}$ - values for the independent variables and for the constant from the regression model confirm the rejection of the null hypothesis and the acceptance of the alternative hypothesis $\mathrm{H}_{1}$.

When we see in detail the coefficient of determination, we claim that its value is $\mathrm{R}^{2}=$ 0.561. Owing to this value, with the independent variables $x_{i 1}$ (LSCI 2017) and $x_{i 2}$ (GCI 20172018) from our model, we explain $56.1 \%$ of the variability of dependent variable $\hat{y}_{i}$ (costs to import 1 TEU to Rotterdam in 2020). There are also other factors and random effects that our model depends on and which are not included in it. They represent the remaining $43.9 \%$ of the variability of the dependent variable.

This analysis says the claim that the linear regression model, which is based on the dependence of costs to import 1 TEU container to Rotterdam on the value of the Liner shipping connectivity index and the value of the Global Competitiveness Index, is statistically significant. 


\section{Conclusion}

The 1987 definition of sustainability put emphasis on such an economic development that would meet the need of the present without compromising the ability of future generations to meet their own needs. The "3E's of sustainability" are represented by economy, equity, and environment as overlapping elements of sustainability and it has been further reinvigorated by the SDG index mapping sustainability across the 17 United Nations Sustainable Development Goals. Consideration of sustainable development reflected also in the Global Competitiveness Index and it has been in the centre of the shift from "globalization so far" (e.g. demand for more, and more diverse goods and services) to "trends changing globalization" (e.g. demand for more fair trade, sustainable and local products) as framed by the European Commission, the McKinsey Global Institute and the OECD, too. Bearing in mind that maritime transport is more ecological than air transport, the purpose of our article was to investigate the impact of connectivity between selected countries by cargo maritime transport on costs to import of 1 TEU container transporting a specific commodity in a specific transportation corridor.

The very existence of the regression model, which is statistically significant claims that there is a type of dependence between the costs to import 1 TEU container and the value of the Liner shipping connectivity index. Based on this fact we accept the hypothesis H1 which claims that the costs to import 1 TEU container from the Southeast Asian ports to Rotterdam are sensitive to changes in the quality and intensity of the connections to global liner shipping network.

Direct relationship between the costs to import 1 TEU container and the value of the Liner shipping connectivity index in our model claims that the costs increase with the growth of the value of the analysed index. In other words, if the quality and intensity of the connections to global liner shipping network is higher (related to the investments into the ships, the container-carrying capacity of the ships, vessel size, growing number of services and container ships companies - all are components of the Lines shipping connectivity index), the costs to import 1 TEU container are higher. It is related to investments above, which have to be incorporated into the cost calculations to import price of $1 \mathrm{TEU}$ container.

Indirect relationship between the costs to import 1 TEU container and the value of the Global Competitiveness Index in our model claims that the costs decrease with the growth of the value of this index. In other words, if the quality of the business environment (the transaction costs depend on the quality of the business environment) is higher, which is related to the reduced transaction costs, the costs to import 1 TEU container are lower. It is related to the investments, which have to improve the quality of the business environment. These investments do not have to be included in import price calculations of 1 TEU container. This is supported by the fact that usually government decisions and the governments themselves are in charge of investments aimed at higher quality of the business environment (macroeconomic perspective) and not the business entities operating in the sector of maritime transport (microeconomic perspective).

Further research will be focused on the same transportation corridor as analysed in this article with its westbound direction. The specific issue to research would also be focused on the costs to import 1 TEU container, but this time not from the Southeast Asian port to Rotterdam, but from the Northwest European ports to Shanghai. In order to ensure harmonized methodology, we will also choose electronic components and supplies as our transported commodity of the value of 20000 USD per 1 FCL TEU container. This will allow us to make a relevant comparison of these two bounds of goods' flows within one and the same transportation corridor and offer our recommendations for the reduction of the analysed import costs. 
The authors acknowledge the kind support of VEGA research project No. 1/0420/19 and VEGA research project No. 1/0777/20.

\section{References}

1. Demsetz, H. (1967). Toward a Theory of Property Rights. The American Economic Review, 57(2), 347-359.

2. Stiglitz, J.E. (2018). Globalization and Its Discontents Revisited. New York and London: W. W. Norton \& Company.

3. Sachs, J. (2020). The Ages of Globalization: Geography, Technology, and Institutions. New York: Columbia University Press.

4. World Bank. (2020). International Comparison Program. World bank. https://www.worldbank.org/en/programs/icp

5. Schwab, K. (ed.) (2017). The Global Competitiveness Report 2017-2018. Geneva: World Economic Forum.

6. Sachs, J., Schmidt-Traub, G., Kroll, C., Durand-Delacre, D., Teksoz, K. (2017). SDG Index and Dashboards Report 2017. New York: Bertelsmann Stiftung and SDSN.

7. World Shipping Council. (2020). Trade Routes. Worldshipping. http://www.worldshipping.org/about-the-industry/global-trade/trade-routes

8. Boon, W., Van Wee, B. (2018). Influence of 3D printing on transport: a theory and experts judgment based conceptual model. Transport Reviews, 38(5), 556-575.

9. Macharis, K., Nocera, S. (2019). The future of freight transport. European Transport Research Review, 11(1), 21.

10. Eurosender. (2020). International Sea Freight Services. Eurosender. https://www.eurosender.com/en/s/services/sea-freight

11. Hansenová, H. (2007). Prepravné služby v podmienkach medzinárodného obchodu. Bratislava: Vydavatel'stvo EKONÓM.

12. Čiderová, D., Kovačević, D., Čerňák, J. (2019). The Brexitologic of Competitiveness. Studia commercialia Bratislavensia, 12(2), 147-171.

13. Zorkóciová, O., Palušková, H. (2020). Vplyv globalizácie na vývoj medzinárodného obchodu a význam cirkulárnej ekonomiky. Ekonomika cestovného ruchu a podnikanie, 12(1). 85-97.

14. Bishop, M.L., Payne, A. (2020). The political economies of different globalizations: theorizing reglobalization. Globalizations, 18(1). 1-21.

15. Free, C., Hecimovic, A. (2020). Global supply chains after COVID-19: the end of the road for neoliberal globalisation? Accounting, Auditing \& Accountability Journal, Early Access September 2020.

16. Sharma, P., Leung, T.Y., Kingshott, R.P.J, Davcik, N.S., Cardinali, S. (2020). Managing uncertainty during a global pandemic: An international business perspective. Journal of Business Research, 116, 188-192.

17. North, D. C. (1991). Institutions, Institutional Change and Economic Performance. New York: Cambridge University Press.

18. Williamson, O. E. (1996). The Mechanisms of Governance. New York: Oxford University Press.

19. Gani, A. (2017). The Logistics Performance Effect in International Trade. The Asian Journal of Shipping and Logistics, 33(4), 279-288. 
20. Börjesson, M., Eliasson, J. (2019). Should values of time be differentiated? Transport Reviews, 39(3), 357-375.

21. Global Infrastructure Connectivity Alliance. (2020). Liner shipping connectivity index (LSCI). https://www.gica.global/activity/liner-shipping-connectivity-index-lsci

22. UNCTAD. (2017). UnctadStat.

https://unctadstat.unctad.org/wds/TableViewer/tableView.aspx?ReportId=92.

23. Bartholdi III, J.J., Jarumaneeroj, P., Ramudhin, A. (2016). A new connectivity index for container ports. Maritime Economics and Logistics, 18(3), 231-249.

24. World Freight Rates. (2020). Freight Calculator.

https://www.worldfreightrates.com/en/freight

25. Meramveliotakis, G. (2020). The Issue of Efficiency and the Role of State in New Institutional Economics: A Critical Perspective. New Political Economy, Early Access February 2020. 


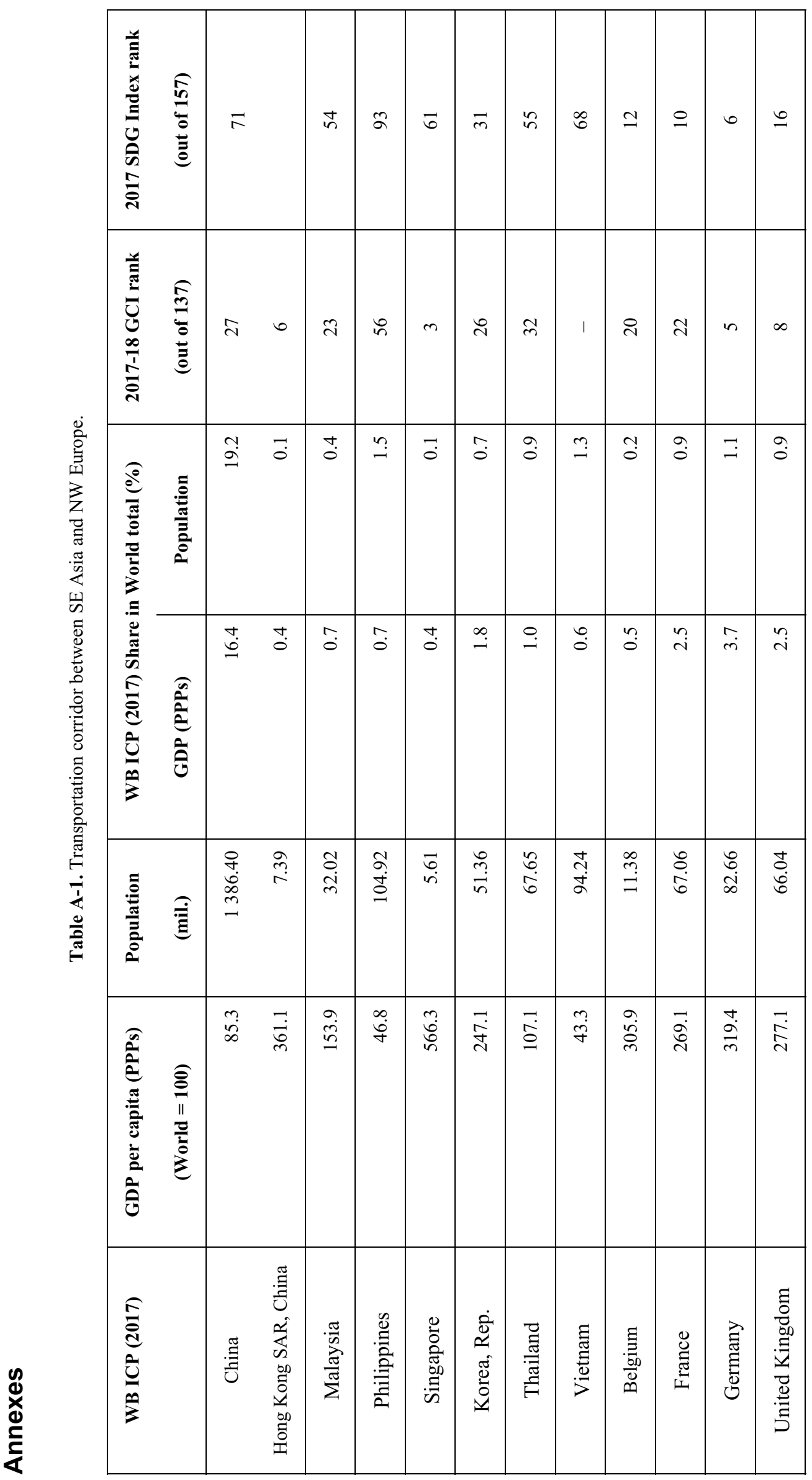


Table A-2. Analysis of the strengths and weaknesses of maritime transport modes.

\begin{tabular}{|c|c|}
\hline Strengths & Weaknesses \\
\hline $\begin{array}{c}\text { Unbeatable in long-haul and } \\
\text { intercontinental transports }\end{array}$ & Low speed \\
\hline Large capacity & Dependence on weather \\
\hline Lowest prices & Higher insurance \\
\hline Good logistics & High investments \\
\hline Basis of multimodality and containerization & Limited commodity structure \\
\hline Developed regular and irregular transport & \\
\hline More ecological than air transport & \\
\hline
\end{tabular}

Source: adapted from [11].

Table A-3. Globalization then and now.

\begin{tabular}{|c|c|}
\hline Globalization so far & Trends changing globalization \\
\hline Tangible flows of physical goods & Intangible flows of services and data \\
\hline $\begin{array}{c}\text { Demand for more, and more diverse } \\
\text { goods and services }\end{array}$ & $\begin{array}{c}\text { Demand for more fair trade, } \\
\text { sustainable and local products }\end{array}$ \\
\hline $\begin{array}{c}\text { Global supply chains } \\
\text { Flows mainly } \\
\text { between developed economies }\end{array}$ & $\begin{array}{c}\text { Greater participation } \\
\text { by emerging economies and megacities }\end{array}$ \\
\hline $\begin{array}{c}\text { States [25] and big multinational companies } \\
\text { drive flows }\end{array}$ & $\begin{array}{c}\text { Growing role of small enterprises, } \\
\text { non-state actors and individuals }\end{array}$ \\
\hline Easily monetised transactions & $\begin{array}{c}\text { Rise of open-source and shared content } \\
\text { Technology transfer } \\
\text { from developed to emerging economies }\end{array}$ \\
\hline
\end{tabular}

Source: European Commission, the McKinsey Global Institute and the OECD cited in [12] 
Table A-4. Summary Statistics, using the observations $1-23$, (missing values were skipped).

\begin{tabular}{|c|c|c|c|c|}
\hline Variable & Mean & Median & Minimum & Maximum \\
\hline $\begin{array}{c}\text { 1_Costs_Import_to_Rot } \\
\text { terdam_2020 }\end{array}$ & 7.2835 & 7.3226 & 7.0764 & 7.4324 \\
\hline 1_LSCI_2017 & 4.4818 & 4.4630 & 3.3362 & 4.9422 \\
\hline 1_GCI_20172018 & 1.6436 & 1.6438 & 1.4702 & 1.7422 \\
\hline Variable & Std. Dev. & C.V. & Skewness & Ex. kurtosis \\
\hline $\begin{array}{c}\text { 1_Costs_Import to_Rot } \\
\text { terdam_2020 }\end{array}$ & 0.11723 & 0.016095 & -0.67486 & -0.91767 \\
\hline 1_LSCI_2017 & 0.40638 & 0.090673 & -1.0291 & 1.2530 \\
\hline 1_GCI_20172018 & 0.077408 & 0.047097 & -0.74803 & 0.040623 \\
\hline Variable & $5 \%$ Perc. & $95 \%$ Perc. & IQ range & Missing obs. \\
\hline $\begin{array}{c}\text { 1_Costs_Import_to_Rot } \\
\text { terdam_2020 }\end{array}$ & undefined & Undefined & 0.18149 & 9 \\
\hline 1_LSCI_2017 & 3.3977 & 4.9422 & 0.55661 & 1 \\
\hline 1_GCI_20172018 & 1.4705 & 1.7409 & 0.098033 & 1 \\
\hline
\end{tabular}

Source: own processing based on data from [5, 21, 24] using Gretl statistical program. 